\title{
Coexistence of Factor V G1691A and Factor II G20210A Gene Mutations in a Thrombotic Family Is Associated with Recurrence and Early Onset of Venous Thrombosis
}

\author{
D. Gemmati M.L. Serino S. Moratelli S. Tognazzo A. Ongaro \\ G.L. Scapoli \\ Centre for the Study of Haemostasis and Thrombosis, University of Ferrara, Italy
}

\section{Key Words}

Factor V G1691A · Prothrombin G20210A . Inherited thrombophilia - Combined defects . Gene-environment interaction

\begin{abstract}
Two G-to-A mutations at positions 1691 of the factor $V(F V)$ gene and 20210 of the prothrombin (FII) gene have been associated with an increased risk of venous thromboembolism. We report a thrombosis-prone family in which one subject - the propositus who exhibited combined heterozygous FV G1691A and FII G20210A mutations showed spontaneous and early clinical onset (at 23 years), recurrences of deep-vein thrombosis and pulmonary embolism. His asymptomatic father carried the FII G20210A substitution and his mother, characterized by an isolated thrombotic episode on occasion
\end{abstract}

\begin{tabular}{ll}
\hline KARGER & ( ) 2001 S. Karger AG, Basel \\
0301-0147/01/0312-0099\$17.50/0 \\
$\begin{array}{l}\text { E-Mail karger@karger.ch } \\
\text { www.karger.com }\end{array}$ & $\begin{array}{l}\text { Accessible online at: } \\
\text { www.karger.com/journals/hae }\end{array}$
\end{tabular}

of surgery (at 48 years), carried the FV G1691A substitution. In the maternal lineage, one of the propositus' uncles had thrombosis on occasion of a bone fracture (at 65 years) despite the absence of known prothrombotic defects. A sister of the propositus carried the FII G20210A and the brother the FV G1691A mutation. They have been asymptomatic until now. The propositus' two children, 20 and 16 years old, both carry the FV G1691A substitution and have been asymptomatic until now. The plasma levels of Fll were higher in carriers of the FII G20210A allele if compared with noncarriers, and the activated protein $C$ resistance phenotype, associated with the FV Leiden mutation, showed a complete correlation with the FV G1691A mutation. Despite the very limited number of thrombotic cases involved in this survey, which does not allow statistically sound conclusions, the data obtained from this family suggest that the syn-
Dr. Donato Gemmati

Centre for the Study of Haemostasis and Thrombosis

University of Ferrara, C.so Giovecca 203

I-44100 Ferrara (Italy)

Tel.+390532 237291, Fax +390532 209010, E-Mail cet@unife.it 
ergy of inherited factors and transient risk conditions could play a key role in the occurrence of thrombotic accidents.

Copyright $@ 2001$ S. Karger AG, Basel

\section{Introduction}

Familial thrombophilia is considered a polygenic and multifactorial disorder in which gene-gene and gene-environment interactions play a pivotal role [1-3]. Point mutations in the factor V (FV) gene (FV G1691A, FV Leiden) [4, 5] and in the prothrombin (FII) gene (FII G20210A) [6] presently account for most cases of inherited thrombophilia. The FV G1691A allele is found in 90$95 \%$ of people with the activated protein $\mathrm{C}$ (APC) resistance phenotype [7]. This suggests that various mechanisms are responsible for the same phenotype [8]. Increased levels of plasma FII are associated with the FII G20210A allele [6,9], but the precise mechanism by which prothrombin levels are altered has yet to be determined. Common inherited prothrombotic factors are associated with a low thrombotic risk compared with the defects that are uncommon but associated with a high risk of thrombosis [10]. Direct evidence from case-control and familial studies suggests that the coexistence of distinct prothrombotic defects increases the risk of developing thrombosis in the presence or absence of transient risk factors [11-17]. In addition, whether or not FV Leiden and FII G20210A mutations separately increase the risk of recurrent venous thrombosis is a debated question, and it has recently been reported that only carriers of both mutations have an increased risk of recurrences and are candidates for lifelong anticoagulant therapy [17]. We describe here a family with asymptomatic subjects carrying inherited prothrombotic defects (i.e. FV Leiden or FII G20210A), the propositus who carries both the FV and FII mutations with spontaneous and recurrent deep venous thrombosis (DVT) and pulmonary embolism in combination with transient risk situations, and his mother who is heterozygous for FV Leiden and has experienced an episode of thrombosis on occasion of surgery. Finally, one of the propositus' uncles had thrombosis despite the absence of known prothrombotic defects.

\section{Patients and Methods}

\section{Family History}

Figure 1 shows the family tree of the family investigated. Subject I4, a 75-year-old woman, had an isolated episode of DVT after an appendicectomy at the age of 48. She was treated with oral anticoagulant therapy for a period of 6 months and she has since been free of thrombosis. One of her two brothers, subject I5, a 73-year-old man, had an isolated episode of DVT at the age of 65 years on occasion of a long period of bed rest because of a fracture of the leg. Subject II4 (the propositus), a 43 -year-old male, had a first spontaneous episode of DVT at the age of 23 years with relapses in the following years. After a period of immobilization owing to a bone fracture, he suffered a further episode of DVT and pulmonary embolism at the age of 32 . He is on lifelong oral anticoagulant therapy. All the remaining members of the family (affected and nonaffected) are currently asymptomatic.

\section{Coagulation Studies}

Anticoagulant response to APC was tested by an activated-partial-thromboplastin-time-based method (ProC ${ }^{\circledR}$ Global, Dade Behring) that was modified as previously described [18]. The results were expressed as normalized APC ratio (nAPC-r; normal values $\geq 0.80$ ). Plasma prothrombin levels (normal values $70-125 \%$ ) were measured using an automated onestage functional assay (Dade Behring). All family members investigated were healthy and asymptomatic at the time of testing and did not receive any pharmacological treatment potentially interfering with coagulation assays.

\section{DNA Analysis}

DNA was extracted from peripheral blood utilizing standard procedures (Puregene ${ }^{\circledR}$, Gentra Systems). For 
Fig. 1. Pedigree of the family investigated. The propositus is indicated by an arrow. $\mathrm{PE}=$ Pulmonary embolism; I1 = deceased subject.

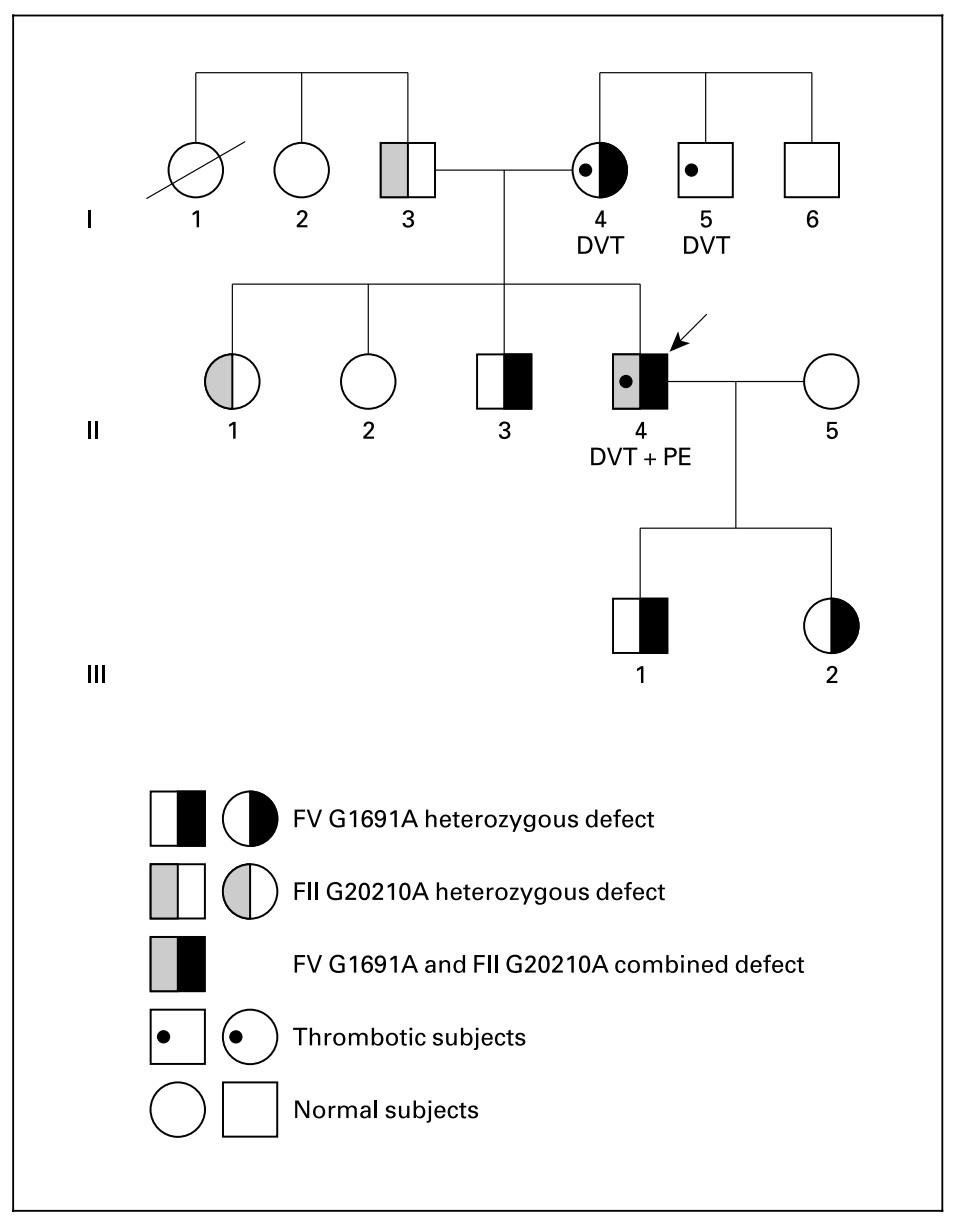

the one-step determination of the FV G1691A and FII G20210A mutations, we utilized multiplex PCR-mediated site-directed mutagenesis, creating a neo-site for TaqI endonuclease in both the FV and FII gene-amplified fragments as recently described by Ripoll [19].

\section{Results}

Table 1 shows the coagulation findings, the DNA analysis related to the FV Leiden and FII mutations and the clinical characteristics of the family investigated. All family members underwent screening for thrombophilia as previously described [20] and none of them exhibited other known risk factors for venous thrombosis.

\section{DNA Studies}

The propositus (subject II4) was heterozygous for both the FV Leiden and the FII gene mutations. The remaining affected family members were heterozygous either for the FV Leiden (subjects I4, II3, III1 and III2) or the FII gene mutation (subjects I3 and II1). The other family members (subjects I2, I5, I6, II2 and II5) did not show either of the mutations (table 1). 
Table 1. Coagulation, genotypic and clinical characteristics of the family investigated

\begin{tabular}{|c|c|c|c|c|c|c|c|}
\hline \multirow[t]{2}{*}{ Subjects } & \multirow{2}{*}{$\begin{array}{l}\text { APC-R } \\
\text { (nAPC-r) }\end{array}$} & \multirow{2}{*}{$\begin{array}{l}\text { FV } \\
\text { G1691A }\end{array}$} & \multirow{2}{*}{$\begin{array}{l}\text { FII } \\
\text { activity, \% }\end{array}$} & \multirow{2}{*}{$\begin{array}{l}\text { FII } \\
\text { G20210A }\end{array}$} & \multicolumn{3}{|c|}{ Thrombosis } \\
\hline & & & & & $\begin{array}{l}\text { age at } \\
\text { onset, years }\end{array}$ & $\begin{array}{l}\text { sponta- } \\
\text { neous }\end{array}$ & $\begin{array}{l}\text { recur- } \\
\text { rence }\end{array}$ \\
\hline $\mathrm{I} 2$ & 0.96 & GG & 100 & GG & - & - & - \\
\hline $\mathrm{I} 3$ & 1.10 & GG & 135 & $\mathrm{G} A$ & - & - & - \\
\hline I4 & 0.65 & $\mathrm{G} A$ & 114 & GG & 48 & no & no \\
\hline I5 & 0.90 & GG & 110 & GG & 65 & no & no \\
\hline I6 & 1.05 & GG & 95 & GG & - & - & - \\
\hline III & 0.99 & GG & 130 & $\mathrm{G} A$ & - & - & - \\
\hline II 2 & 1.15 & GG & 95 & GG & - & - & - \\
\hline II3 & 0.67 & $\mathrm{G} A$ & 100 & GG & - & - & - \\
\hline II $4^{1}$ & 0.60 & $\mathrm{G} A$ & 150 & $\mathrm{G} A$ & 23 & yes & yes \\
\hline II5 & 1.25 & GG & 125 & GG & - & - & - \\
\hline III1 & 0.70 & $\mathrm{G} A$ & 105 & GG & - & - & - \\
\hline III2 & 0.66 & $\mathrm{G} A$ & 100 & GG & - & - & - \\
\hline Normal & $\geq 0.80$ & GG & $70-125$ & GG & - & - & - \\
\hline
\end{tabular}

The pathologic findings are shown in italics.

1 Propositus.

\section{Coagulation Studies}

The subjects who carried the FII G20210A mutation had plasma levels of prothrombin above the upper limit of the normal range $(70-125 \%)$ and of the levels observed in the subjects with a normal FII genotype (95$125 \%)$. The APC resistance phenotype associated with FV Leiden, measured as nAPC-r, showed a complete correlation with DNA analysis being below the normal cutoff value (nAPC-r $=0.80$ ) in all the individuals with the FV Leiden mutation. It is of note that the propositus showed the highest prothrombin level and the lowest nAPC-r value of the family members investigated (table 1).

\section{Discussion}

When genetic defects are absent, thrombosis occurs in the older population, often with strong environmental risks such as surgery, bone fractures or cancer [1-3]. In contrast, inherited thrombosis is associated with younger age of onset; it is due to the presence of one or more genetic defects in which gene-gene and gene-environment interactions play a role [1-3]. FV Leiden and FII G20210A mutations account for most cases of inherited thrombophilia and they are relatively common among Caucasians [21, 22]. Therefore thrombotic patients with combined defects are not so rare.

We describe a family in which the propositus (II4) was characterized by the combined presence of heterozygous FV Leiden and FII G20210A mutations. The severity of symptoms, the recurrences and the early onset of a spontaneous thrombosis together with a positive family history recommended a long-term anticoagulant treatment. These features could be due to the coexistence of two inherited prothrombotic defects in conjunction with important triggering factors such as bone frac- 
ture and immobilization. Most likely, these were the only prothrombotic conditions in the propositus, since all family members underwent screening for thrombophilia, which did not reveal any other genetic defects. The propositus' mother (I4) and one of her two brothers (I5), were the other symptomatic members of the family. The mother was heterozygous for the FV Leiden mutation and had an isolated thrombosis on occasion of surgery at age 48. After anticoagulant treatment was stopped she remained free of thrombosis until today. De Stefano et al. [17] reported that in patients with only an FV Leiden mutation, the risk of recurrences was nearly identical to that in patients with no mutation, regardless of the type of recurrence (any, spontaneous, spontaneous after either a first idiopathic event or in conjunction with defined risk factors). The risk of spontaneous recurrences in the propositus' mother should fall within the latter subgroup, since she had her first episode on occasion of surgery. It is of note that she had had four pregnancies with no complications in the period from 23 to 32 years. Transient risk situations such as pregnancy, childbirth, surgery and trauma are known risk factors for thrombosis, especially in genetically affected subjects in whom they could act as precipitating factors. However, not all subjects carrying an FV Leiden mutation experience thrombosis [23-25]. The increased risk of thrombosis is lifelong and increases with age. In a study of 50 Swedish families with inherited APC resistance, the thrombosis-free survival curves showed that at 33 years of age only $20 \%$ of heterozygotes and $40 \%$ of homozygotes had manifestations of venous thrombosis [7]. The propositus' mother had pregnancies when she was relatively young (23-32 years), and established prothrombotic risk factors did not cause any clinical accident in her, while at older age thrombosis occurred on occasion of surgery. The modulatory role of age in combination with circumstantial risk situations at the onset of thrombosis in genetically predisposed patients is clearly shown in this case. Finally, in the maternal lineage, subject $\mathrm{I} 5 \mathrm{had}$ thrombosis in the absence of known prothrombotic defects, following a long period of immobilization due to a bone fracture. The importance of coinherited genetic risk factors and environmental risk conditions in the occurrence of thrombosis is well demonstrated by the present study, although in this patient (subject I5) no congenital defects were found. It is of note that in this subject thrombosis occurred at an older age and in combination with strong environmental risk conditions. However, it could be speculated that some inherited predisposition was present in him, since thrombosis occurred in his sister too.

To summarize, in this family thrombosis occurred in the propositus who exhibited combined FV and FII mutations, with a first idiopathic episode (at 23 years) and further recurrences in conjunction with acquired risk conditions, his mother who had an FV mutation suffered an isolated episode on occasion of surgery (at 48 years) and an uncle of the propositus also experienced an isolated episode despite the absence of prothrombotic defects (at 65 years). This means that the maternal lineage, where other unidentified prothrombotic influences could be present, can be identified as the thrombosis-prone lineage in which most likely common prothrombotic polymorphisms can cause familial thrombosis. On the other hand, all family members, affected and nonaffected ones, have a finite risk of developing thrombosis. In a recent large study on family members with FV and/or FII gene mutations, Martinelli et al. [26] reported that the absolute annual risk of a first episode of venous thrombosis was higher in carriers of both mutations $(0.42 \%)$ and lower in cases with either mutation $(0.19$ 
and $0.13 \%$ for FV and FII gene mutation, respectively) compared with $0.066 \%$ in relatives with neither mutation. In particular, a recent report on the risk assessment of single and combined prothrombotic polymorphisms in patients with idiopathic venous thromboembolism ascribed the highest risk to the coexistence of the FV Leiden and the FII gene mutations [17]. Moreover, in thrombophilic families, the FII G20210A allele was recently found to be associated more frequently with the FV G1691A mutation than with the protein $\mathrm{S}$ defect [27].

In the family we studied, the combination of asymptomatic and genetically affected subjects and a thrombotic relative who is genetically unaffected is in accordance with the multifactorial nature of thrombosis and raises the problem whether the presence or absence of defined prothrombotic defects (i.e. FV Leiden or FII gene mutations) should influence the use of primary prophylaxis or the duration of treatment after an episode of thrombosis [26]. The decision should take into account that the risk of thrombosis has to be weighed against the risk of bleeding associated with oral anticoagulation ranging from 1.1 to $3.8 \%$ per patient-year $[28,29]$.

Notwithstanding the limitations of our survey due to the small size of the population studied and the fact that up till today it is not certain whether FV Leiden or FII gene mutations are by themselves independent risk factors for venous thrombosis, the presented family could be a good model which allows to highlight and to discuss the multifactorial and polygenic nature of thrombosis in which inherited and acquired conditions act in synergism on the onset and progression of venous thromboembolism.

\section{Acknowledgments}

This study was supported in part by Italian MURST funds and by a grant from Azienda Ospedaliera Sant'Anna, Ferrara, Italy.

\section{References}

1 Lane DA, Mannucci PM, Bauer KA, Bertina RM, Bochkov NP, Boulyjenkov V, Chandy M, Dahlback B, Ginter EK, Miletich JP, Rosendaal FR, Seligsohn U: Inherited thrombophilia: Part 1. Thromb Haemost 1996;76:651-662.

2 Lane DA, Mannucci PM, Bauer KA, Bertina RM, Bochkov NP, Boulyjenkov V, Chandy M, Dahlback B, Ginter EK, Miletich JP, Rosendaal FR, Seligsohn U: Inherited thrombophilia: Part 2. Thromb Haemost 1996;76:824-834.

3 Lane DA, Grant PJ: Role of hemostatic gene polymorphisms in venous and arterial thrombotic disease. Blood 2000;95:1517-1532.
4 Dahlback B, Carlsson M, Svensson PJ: Familial thrombophilia due to a previously unrecognized mechanism characterized by poor anticoagulant response to activated protein C: Prediction of a cofactor to activated protein C. Proc Natl Acad Sci USA 1993;90:1004-1008.

5 Bertina RM, Koeleman BP, Koster T, Rosendaal FR, Dirven RJ, de Ronde H, van der Velden PA, Reitsma PH: Mutation in blood coagulation factor $\mathrm{V}$ associated with resistance to activated protein C. Nature 1994;369:64-67.

6 Poort SR, Rosendaal FR, Reitsma $\mathrm{PH}$, Bertina RM: A common genetic variation in the $3^{\prime}$-untranslated region of the prothrombin gene is associated with elevated plasma prothrombin levels and an increase in venous thrombosis. Blood 1996;88: 3698-3703.
7 Zoller B, Svensson PJ, He X, Dahlback B: Identification of the same factor $\mathrm{V}$ gene mutation in 47 out of 50 thrombosis-prone families with inherited resistance to activated protein C. J Clin Invest 1994;94: 2521-2524.

8 Bernardi F, Faioni EM, Castoldi E, Lunghi B, Castaman G, Sacchi E, Mannucci PM: A factor V genetic component differing from factor $\mathrm{V}$ R506Q contributes to the activated protein $\mathrm{C}$ resistance phenotype. Blood 1997;90:1552-1557.

9 Soria JM, Almasy L, Souto JC, Tirado I, Borell M, Mateo J, Slifer S, Stone W, Blangero J, Fontcuberta J: Linkage analysis demonstrates that the prothrombin G20210A mutation jointly influences plasma prothrombin levels and risk of thrombosis. Blood 2000;95:2780-2785. 
10 Kearon C, Crowther M, Hirsh J: Management of patients with hereditary hypercoagulable disorders. Annu Rev Med 2000;51:169-185.

11 Pecheniuk NM, Marsh NA, Walsh TP: Multiple analysis of three common genetic alterations associated with thrombophilia. Blood Coagul Fibrinolysis 2000;11:183-189.

12 Gemmati D, Serino ML, Moratelli S, Mari R, Ballerini G, Scapoli GL: Coexistence of antithrombin deficiency, factor V Leiden and hyperhomocysteinemia in a thrombotic family. Blood Coagul Fibrinolysis 1998;9:173-176.

13 Tosetto A, Rodeghiero F, Martinelli I, De Stefano V, Missiaglia E, Chiusolo P, Mannucci PM: Additional genetic risk factors for venous thromboembolism in carriers of the factor V Leiden mutation. Br J Haematol 1998;103:871-876.

14 Castaman G, Tosetto A, Cappellari A, Ruggeri M, Rodeghiero F: The A20210 allele in the prothrombin gene enhances the risk of venous thrombosis in carriers of inherited protein S deficiency. Blood Coagul Fibrinolysis 2000;11:321-326.

15 van Boven HH, Reitsma PH, Rosendaal FR, Bayston TA, Chowdhury V, Bauer KA, Scharrer I, Conard J, Lane DA: Factor V Leiden (FV R506Q) in families with inherited antithrombin deficiency. Thromb Haemost 1996;75:417-421.

16 Mitsis M, Ioannou H, Eleftheriou A, Nousias V, Basioukas C, Kakosimos G, Batsis C, Vartholomatos G: Combined genetic defect (homogeneity for factor V Leiden and heterogeneity for prothrombin G20210A allele), in a young patient, with recurrent deep vein thrombosis and serious postphlebitic syndrome - A case report. Angiology 2000;51: 325-329.
17 De Stefano V, Martinelli I, Mannucci PM, Paciaroni K, Chiusolo P, Casorelli I, Rossi E, Leone G: The risk of recurrent deep venous thrombosis among heterozygous carriers of both factor $\mathrm{V}$ Leiden and the G20210A prothrombin mutation. N Engl J Med 1999;341:801-806.

18 Gemmati D, Serino ML, Scapoli GL: A modified functional global test to measure protein $\mathrm{C}$, protein $\mathrm{S}$ activities and the activated protein C-resistance phenotype. Thromb Res 1998;92:141-148.

19 Ripoll L, Paulin D, Thomas S, Drouet LO: Multiplex PCR-mediated site-directed mutagenesis for one-step determination of factor $\mathrm{V}$ Leiden and G20210A transition of the prothrombin gene. Thromb Haemost 1997;78:960-961.

20 Gemmati D, Previati M, Serino ML, Moratelli S, Guerra S, Capitani S, Forini E, Ballerini G, Scapoli GL: Low folate levels and thermolabile methylenetetrahydrofolate reductase as primary determinant of mild hyperhomocystinemia in normal and thromboembolic subjects. Arterioscler Thromb Vasc Biol 1999; 19:1761-1767.

21 De Stefano V, Chiusolo P, Paciaroni K, Leone G: Epidemiology of factor V Leiden: Clinical implications. Semin Thromb Hemost 1998;24: 367-379.

22 Rosendaal FR, Doggen CJ, Zivelin A, Arruda VR, Aiach M, Siscovick DS, Hillarp A, Watzke HH, Bernardi F, Cumming AM, Preston FE, Reitsma PH: Geographic distribution of the $20210 \mathrm{G}$ to A prothrombin variant. Thromb Haemost 1998; 79:706-708.

23 Gemmati D, Serino ML, Verzola I, Mari R, Moratelli S, Ballerini G: Resistance to activated protein $\mathrm{C}$ and low levels of protein $\mathrm{S}$ activity in nine thrombophilic families: A correct diagnosis. Blood Coagul Fibrinolysis 1997;8:118-123.
24 Gemmati D, Serino ML, Mari R, Verzola I, Moratelli S, Ballerini G: Different anticoagulant response to activated protein C (APC test) and to Agkistrodon contortrix venom (ACV test) in a family with FVR506Q substitution. Clin Appl Thromb Hemost 1997;3:168-173.

25 Hillarp A, Dahlback B, Zoller B: Activated protein $\mathrm{C}$ resistance: From phenotype to genotype and clinical practice. Blood Rev 1995;9:201212.

26 Martinelli I, Bucciarelli P, Margaglione M, De Stefano V, Castaman G, Mannucci PM: The risk of venous thromboembolism in family members with mutations in the genes of factor $\mathrm{V}$ or prothrombin or both. Br J Haematol 2000;111: 1223-1229.

27 Zoller B, Svensson PJ, Dahlback B, Hillarp A: The A20210 allele of the prothrombin gene is frequently associated with the factor V Arg 506 to Gln mutation but not with protein S deficiency in thrombophilic families. Blood 1998;91:2210-2211.

28 Palareti G, Leali N, Coccheri S, Poggi M, Manotti C, D'Angelo A, Pengo V, Erba N, Moia M, Ciavarella N, Devoto G, Berrettini M, Musolesi S: Bleeding complications of oral anticoagulant treatment: An inceptioncohort, prospective collaborative study (ISCOAT). Italian Study on Complications of Oral Anticoagulant Therapy. Lancet 1996;348: 423-428.

29 Kearon C, Gent M, Hirsh J, Weitz J, Kovacs MJ, Anderson DR, Turpie AG, Green D, Ginsberg JS, Wells P, MacKinnon B, Julian JA: A comparison of three months of anticoagulation with extended anticoagulation for a first episode of idiopathic venous thromboembolism. N Engl J Med 1999;340:901-907. 